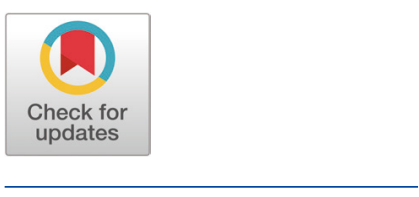

Received: Oct 23, 2019

Revised: Dec 27, 2019

Accepted: Jan 8, 2020

\#These authors contributed equally to this work.

*Corresponding author

Hack-Youn Kim

Department of Animal Resources

Science, Kongju National University,

Yesan 32439, Korea.

Tel: +82-41-330-1241

E-mail: kimhy@kongju.ac.kr

Gye-Woong Kim

Department of Animal Resources

Science, Kongju National University,

Yesan 32439, Korea.

Tel: +82-41-330-1245

E-mail: kimgoong@kongju.ac.kr

Copyright $\odot 2020$ Korean Society of Animal Sciences and Technology.

This is an Open Access article distributed under the terms of the Creative Commons Attribution Non-Commercial License (http:// creativecommons.org/licenses/by$\mathrm{nc} / 4.0 /$ ) which permits unrestricted non-commercial use, distribution, and reproduction in any medium, provided the original work is properly cited.

ORCID

Sin-Young Park

https://orcid.org/0000-0001-7900-5987

Tae-Seok Oh

https://orcid.org/0000-0002-2471-9672

Gye-Woong Kim

https://orcid.org/0000-0001-7325-9898

\section{Quality properties of various dietary fibers as isolated soy protein (ISP) replacements in pork emulsion systems}

\author{
Sin-Young Park ${ }^{1 \#}$, Tae-Seok Oh ${ }^{2 \#}$, Gye-Woong Kim ${ }^{1 *}$ and Hack-Youn Kim ${ }^{1 *}$ \\ ${ }^{1}$ Department of Animal Resources Science, Kongju National University, Yesan 32439, Korea \\ ${ }^{2}$ Department of Plant Resources, Kongju National University, Yesan 32439, Korea
}

\section{Abstract}

This study aimed to investigate the possibility of replacing the isolated soy protein (ISP) as a binding agent for wheat, oat, and bamboo shoot dietary fibers. Dietary fibers and ISP were added to manufacturing process of pork emulsion, respectively, for investigate quality properties. Moisture contents of pork emulsion added wheat fiber-treated group was significantly higher than ISP-treated group $(p<0.05)$, and protein contents of dietary fiber-treated group were significantly lower than ISP-treated group $(p<0.05)$. Raw pork emulsion CIE $a^{*}$ value of oat, bamboo shoot fiber-treated group were significantly lower than ISP-treated group ( $p$ $<0.05$ ). After cooking pork emulsion $\mathrm{CIE} L^{*}$ value of dietary fiber-treated group were significantly higher than ISP-treated group $(p<0.05)$. Raw pork emulsion water holding capacity $(\mathrm{WHC})$ of wheat, oat fiber-treated group were significantly higher than ISP-treated group ( $p$ $<0.05$ ), and cooked pork emulsion WHC of wheat, bamboo shoot fiber-treated group were higher than ISP-treated group $(p<0.05)$. Cooking loss of ISP-treated group was significantly higher than dietary fiber-treated group $(p<0.05)$, and viscosity of ISP-treated group was lower than dietary fiber-treated group. Hardness of ISP-treated group was significantly lower than dietary fiber-treated group $(p<0.05)$; however, cohesiveness of ISP-treated group was significantly higher than dietary fiber-treated group $(p<0.05)$. In conclusion, dietary fiber added as binding agent to manufacturing process of pork emulsion was suitable to replacing ISP. Keywords: Binding agent, Dietary fiber, ISP, Pork emulsion, Quality properties

\section{INTRODUCTION}

Isolated soy protein (ISP) is an food additive produced by isolating the proteins from soy (soybeans); it exhibits a protein content $\geq 90 \%$ [1]. In meat processing industries, ISP is used as an agent for binding and bulking during the production of emulsified meat. Its outstanding ability to bind with water and fat makes it a useful additive for enhancing the water holding capacity (WHC), emulsifying capacity, swelling, viscosity, gelling, and solubility of emulsified meat [1].

Another additive with similar functions to those of ISP with respect to binding and bulking is dietary fiber [2]. For meat (processed meat) products, the addition of various forms of dietary fiber in- 
Hack-Youn Kim

https://orcid.org/0000-0001-5303-4595

Competing interests

No potential conflict of interest relevant to

this article was reported.

Funding sources

This work was supported by the research grant of the Kongju National University in 2019.

Acknowledgements

Not applicable.

Availability of data and material Upon reasonable request, the datasets of this study can be available from the corresponding author.

Authors' contributions Conceptualization: Kim HY, Oh TS.

Data curation: Kim HY, Oh TS.

Formal analysis: Park SY.

Methodology: Kim GW.

Software: Park SY.

Validation: Kim HY, Kim GW.

Investigation: Park SY.

Writing - original draft: Park SY, Oh TS.

Writing - review \& editing: Kim HY, Kim GW.

Ethics approval and consent to participate This article does not require IRB/IACUC approval because there are no human and animal participants. creases the cooking yield of the product while enhancing its emulsifying capacity and texture; thus, they have been applied to processed meat products [3]. Dietary fiber is rich in foods such as vegetables, fruits, and seaweeds. It is a macromolecular carbohydrate that is excreted from the human body without being digested by digestive enzymes [4]. Dietary fiber has also been reported to exert positive effects in lowering plasma cholesterol and fat levels as well as in diabetes treatment, while reducing the incidence of cardiovascular diseases [2,5].

The different forms of dietary fiber that can be applied to processed meat products include wheat, oat, and bamboo shoot fibers. Oat fiber has various properties, including the ability to absorb moisture; its use has been reported to have positive effects in producing fat-free frankfurters and low-fat bologna sausages [6]. Choi et al. [7] studied the replacement of ISP by wheat fiber in pork emulsion and reported that the quality properties did not deteriorate, thereby verifying the potential use of wheat fiber as a replacement. In a study on the addition of wheat and oat fibers to Chinese sausages, the original products and those to which dietary fiber was added did not show a significant difference in quality, thereby indicating their wide spectrum of use [8]. Bamboo shoot fiber, as an agent for bulking, is known to improve the WHC of meat products [2].

The present study aimed to investigate the addition of wheat, oat, and bamboo shoot fibers as potential replacements of ISP acting as a binding agent in pork emulsion products and to analyze their quality properties.

\section{MATERIALS AND METHODS}

\section{Preparation of samples}

Pork ham (refrigerated for 24h after slaughter, Misochan, Chungnam, Korea) were used for pork emulsion for the test. Pork ham and back fat were ground using a grinder with equip plates of 3 $\mathrm{mm}$. Minced pork ham (60\%), back fat (20\%), and ice (20\%) were finely cut using a bowl cutter (K30, Talsa, Valencia, Spain), added with $\mathrm{NaCl}(1.2 \%)$ and different forms of binding agents (ISP: 1\%, PROFAM 974, ADM, IL, USA; wheat fiber: 2\%, WF200, JRS, Rosenberg, Germany; oat fiber: 2\%, JRS, Rosenberg, Germany; bamboo shoot fiber: 2\%, JRS, Rosenberg, Germany) were added in proportion to the total weight to produce a pork emulsion. This pork emulsion was filled in a conical tube (50 mL conical tube, SPL, Korea) using a stuffer (EM-12, Mainca, Barcelona, Spain), followed by filled pork emulsion was thermally processed in an $80^{\circ} \mathrm{C}$ chamber $(10.10 \mathrm{ESI} / \mathrm{SK}$, Alto Shaam, WI, USA) for $30 \mathrm{~min}$, and then cooling at $10^{\circ} \mathrm{C}$ for $30 \mathrm{~min}$.

\section{Proximate composition}

The proximate composition was measured following methods in compliance with the AOAC [9]. Moisture content was measured by sample $1 \mathrm{~g}$ in a drying oven at $105^{\circ} \mathrm{C}$ for $24 \mathrm{~h}$. Crude protein content was measured by Kjeldahl method. Crude fat content was measured by Soxhlet method. Ash content was measured by sample $1 \mathrm{~g}$ in a furnace at $600^{\circ} \mathrm{C}$ for $4 \mathrm{~h}$.

\section{Color}

The inner surface of the samples before and after heating was measure using a color reader (CR-10, Minolta, Tokyo, Japan) for CIE L* (lightness), CIE a* (redness), and CIE b* (yellowness). A white standard plate with a CIE $L^{*}$ of $+97.83, \mathrm{CIE} \mathrm{a}^{*}$ of -0.43 , and $\mathrm{CIE} \mathrm{b}^{*}$ of +1.98 was used as reference.

$\mathrm{pH}$

For measuring $\mathrm{pH}$, each $5 \mathrm{~g}$ sample was placed in a conical tube along with $20 \mathrm{~mL}$ distilled water. After sample preparation, homogenizing using a ultra-turrax homogenizer (HMZ-20DN, Poolim 
Tech, Seongnam, Korea) at 10,000 rpm for $1 \mathrm{~min}$. The $\mathrm{pH}$ of prepared mixture was measured using a pH meter (Model S220, Mettler-Toledo, Schwerzenbach, Switzerland).

\section{Water holding capacity (WHC)}

The WHC determined was slightly modified method of the Cabling et al. [10]. Each treatment $5 \mathrm{~g}$ was put in a conical tube covered with cotton, and cover filter paper up close the lid. Centrifugation using a centrifuge (Supra R22, Hanil, Gimpo, Korea) of prepared sample in an 1,092 $\times g, 4^{\circ} \mathrm{C}$ centrifuge for $10 \mathrm{~min}$. After centrifugation, WHC calculated using the following methods by measuring weight of water-drained sample.

$$
\text { WHC }(\%)=\frac{A-B}{B} \times 100
$$

A: (Weight of before centrifugation $(\mathrm{g}) \times$ Water content $(\%)) / 100$

$\mathrm{B}$ : Weight of before centrifugation $(\mathrm{g})$ - Weight of after centrifugation $(\mathrm{g})$

\section{Emulsion stability}

The emulsion stability was measured following by the method of Ensor et al. [11]. A 15 mesh sieve $(4 \times 4 \mathrm{~cm})$ was placed in the middle of a glass tube. Pork batter $(30 \mathrm{~g}$, respectively) from each treatment was on the sieve in glass tubes, which were then covered. Samples from each treatment were cooked at $80^{\circ} \mathrm{C}$ for $40 \mathrm{~min}$. After cooling to $4^{\circ} \mathrm{C}$ for facilitate fat and water layer separation. The water and fat, which separated in the glass tube for emulsion stability, were measured in milliliter and calculated as a percentage of the original weight of batter.

$$
\begin{aligned}
& \text { Water loss }(\%)=\frac{\text { Water exudation layer }(\mathrm{mL})}{\text { Raw meat batter weight }(\mathrm{g})} \times 100 \\
& \text { Fat loss }(\%)=\frac{\text { Fat exudation layer }(\mathrm{mL})}{\text { Raw meat batter weight }(\mathrm{g})} \times 100
\end{aligned}
$$

\section{Cooking loss}

The uncooked pork emulsion (weight before cooking) heat processed at chamber $\left(80^{\circ} \mathrm{C}, 30 \mathrm{~min}\right)$, After cooling for $10^{\circ} \mathrm{C}, 1 \mathrm{~h}$, cooking samples were weighed (weight after cooking) and a percentage cooking loss was calculated made according to following formula.

$$
\text { Cooking loss }(\%)=\frac{\text { Weight before cooking }- \text { Weight after cooking }(\mathrm{g})}{\text { Weight before cooking }(\mathrm{g})} \times 100
$$

\section{Viscosity}

The viscosity of the meat emulsion was measured using a rotational viscometer (Merlin VR, Rheosys, NJ, USA). The sample was placed on a parallel plate of $30 \mathrm{~mm}$ with a gap of $2.0 \mathrm{~mm}$, and measurement was conducted in $60 \mathrm{~s}$ at $20^{\circ} \mathrm{C}$ with a head speed of $20 \mathrm{rpm}$ [12].

\section{Texture profile analysis (TPA)}

The texture of the sample was measured using a texture analyzer (TA 1, Lloyd, FL, USA). Samples were cut into sections with a height $2 \mathrm{~cm}$ and $\varphi 2.5 \mathrm{~cm}$ diameter and measured at room temperature, with the following settings: a cylinder probe of $100 \mathrm{~mm}$ with a pre-test speed of $2.0 \mathrm{~mm} / \mathrm{s}$, a post-test speed of $5.0 \mathrm{~mm} / \mathrm{s}$, a maximum load of $2 \mathrm{~kg}$, a head speed of $2.0 \mathrm{~mm} / \mathrm{s}$, a distance of 8.0 
$\mathrm{mm}$, and a force of $5 \mathrm{~g}$. Hardness $(\mathrm{N})$, springiness, and cohesiveness were measured and recorded, which were utilized for calculating gumminess $(\mathrm{N})$ and chewiness $(\mathrm{N})$.

\section{Statistical analysis}

All analysis results were assessed after a minimum of three repeated trials. Analysis of variance were performed on all variables measured using the General Linear Model (GLM) procedure of the SAS software program (SAS version 9.3 for window; SAS Institute Inc., NC, USA), ANOVA and significant differences $(p<0.05)$ were detected by Duncun's multiple range test. The results were indicated as means values and standard deviation.

\section{RESULTS AND DISCUSSION}

\section{Proximate analysis}

The proximate composition of the pork emulsions produced using different forms of dietary fiber and ISP is presented in Table 1. ISP retains the moisture in meat and has the ability to prevent the separation of water molecules during the cooking process $[13,14]$. For moisture content, a significantly higher content was exhibited by the wheat fiber-treated group than the ISP-treated group $(p<0.05)$, while the oat and bamboo shoot fiber groups did not show a significant difference from the ISP group. An increase in the moisture content upon the addition of dietary fiber to emulsified meat products was reported in previous studies $[15,16]$. The increase is due to the ISP-like water and fat binding ability of dietary fiber [2]. For protein content, all dietary fiber-treated groups showed a significantly lower content than the ISP-treated group $(p<0.05)$. ISP is an agent that is isolated and extracted from soybean proteins; it exhibits a protein content $\geq 90 \%$ [13], which was likely the reason for its relatively high protein content in comparison with those of the other treatment groups. For fat and ash content did not differ significantly across all treatment groups; this result agreed with that of a previous study that added carrot fiber to ground processed meat products and found no significant difference in fat and ash content caused by the addition of dietary fiber $(3 \%-12 \%)[17]$.

\section{CIE color}

The CIE color of the pork emulsions produced using different forms of dietary fiber and ISP is presented in Table 2. The redness of the raw pork emulsion did not show a difference between the wheat fiber-treated and ISP-treated groups, while the oat and bamboo shoot fiber-treated groups displayed a significantly lower value than the ISP-treated group $(p<0.05)$. The lightness after cooking showed significantly higher values across all dietary fiber-treated groups compared with the

Table 1. Proximate composition of pork emulsion formulated with different forms of dietary fiber and ISP

\begin{tabular}{lcccc}
\hline \multirow{2}{*}{ Traits } & \multicolumn{4}{c}{ Types of binding agent } \\
\cline { 2 - 5 } & ISP (control) & Wheat & Oat & Bamboo shoot \\
\hline Moisture (\%) & $49.18 \pm 1.02^{\mathrm{b}}$ & $54.49 \pm 2.22^{\mathrm{a}}$ & $53.69 \pm 1.25^{\mathrm{ab}}$ & $53.5 \pm 3.94^{\mathrm{ab}}$ \\
Protein (\%) & $14.82 \pm 0.29^{\mathrm{a}}$ & $13.94 \pm 0.27^{\mathrm{b}}$ & $12.89 \pm 0.06^{\mathrm{b}}$ & $13.59 \pm 0.12^{\mathrm{b}}$ \\
Fat (\%) & $21.99 \pm 1.01$ & $22.64 \pm 0.58$ & $19.70 \pm 0.71$ & $20.67 \pm 2.62$ \\
Ash (\%) & $3.44 \pm 1.57$ & $2.42 \pm 0.11$ & $2.25 \pm 0.69$ & $2.59 \pm 0.33$ \\
\hline
\end{tabular}

All values are mean $\pm S D$.

${ }^{a, b}$ Means in the same row with different letters are significantly different $(p<0.05)$

ISP, isolated soy protein. 
Table 2. CIE color of pork emulsion formulated with different forms of dietary fiber and ISP

\begin{tabular}{lllllc}
\hline \multirow{2}{*}{ Traits } & & \multicolumn{4}{c}{ Types of binding agent } \\
\cline { 3 - 6 } & & ISP (control) & Wheat & Oat & Bamboo shoot \\
\hline Uncooked & $\mathrm{L}^{*}$ & $67.25 \pm 0.88$ & $67.43 \pm 0.15$ & $67.83 \pm 1.02$ & $67.68 \pm 0.29$ \\
& $\mathrm{a}^{*}$ & $21.58 \pm 2.59^{\mathrm{a}}$ & $20.03 \pm 0.44^{\mathrm{ab}}$ & $18.02 \pm 1.89^{\mathrm{bc}}$ & $15.85 \pm 0.31^{\mathrm{c}}$ \\
& $\mathrm{b}^{*}$ & $16.23 \pm 0.60^{\mathrm{b}}$ & $16.63 \pm 0.10^{\mathrm{b}}$ & $16.74 \pm 1.37^{\mathrm{b}}$ & $18.43 \pm 0.39^{\mathrm{a}}$ \\
\hline Cooked & $\mathrm{L}^{*}$ & $66.83 \pm 0.49^{\mathrm{b}}$ & $69.60 \pm 0.15^{\mathrm{a}}$ & $70.08 \pm 0.78^{\mathrm{a}}$ & $69.72 \pm 0.37^{\mathrm{a}}$ \\
& $\mathrm{a}^{*}$ & $19.30 \pm 1.07$ & $19.85 \pm 0.91$ & $20.62 \pm 2.70$ & $18.06 \pm 1.66$ \\
& $\mathrm{~b}^{*}$ & $11.63 \pm 0.69^{\mathrm{b}}$ & $11.85 \pm 0.34^{\mathrm{b}}$ & $12.04 \pm 0.72^{\mathrm{b}}$ & $15.20 \pm 2.73^{\mathrm{a}}$ \\
\hline
\end{tabular}

All values are mean $\pm S D$.

${ }^{a-c}$ Means in the same row with different letters are significantly different $(p<0.05)$.

ISP, isolated soy protein.

ISP-treated group $(p<0.05)$. The yellowness showed higher values in the bamboo shoot fiber-treated group than in the other treatment groups $(p<0.05)$. The CIE colors of ISP ( $L^{*}: 68.46, a^{*}: 1.44$, $b^{*}: 9.90$ ) and dietary fiber (wheat fiber: $L^{*} 87.88, a^{*} 1.78, b^{*} 9.34$; oat fiber: L* $89.12, a^{*} 1.82, b^{*} 9.78$; bamboo shoot fiber: $\left.L^{*} 91.56, a^{*} 1.60, b^{*} 8.42\right)$ used in this study were found to exhibit the largest difference in lightness. This was likely due to the higher value of lightness in dietary fiber than that in ISP, which led to the higher value of lightness in emulsified meat after cooking. For certain forms of dietary fiber, the fiber's unique color is applied to enhance the color of the meat product [2], and an increase in lightness has been reported in several studies where dietary fiber was added to meat products $[8,15,18]$.

\section{$\mathrm{pH}$ and $\mathrm{WHC}$}

The $\mathrm{pH}$ of the pork emulsions produced using different forms of dietary fiber and ISP is presented in Table 3. Before cooking, the $\mathrm{pH}$ of the raw pork emulsion based on the type of binding agent was in the range of 5.65-5.68, which increased to 5.79-5.81 after cooking; however, the difference across the treatment groups was not significant. When different forms of dietary fiber (lemon albedo, wheat, and oat) were added to emulsified or ground meat products, the $\mathrm{pH}$ did not change according to the added amount $[8,15]$. In the production of sausage emulsion, the addition of wheat fiber as an ISP replacement did not lead to a difference in $\mathrm{pH}$ across the treatment groups [7], which was in line with the results of this study. Nonetheless, the addition of certain forms of dietary fiber to processed meat products does cause a change in $\mathrm{pH}[16,18]$, which is likely owing to the individual characteristics of each dietary fiber. ISP and dietary fiber are known to absorb and bind to water $[2,13,14]$, and ISP has been widely used as a binding or bulking agent in the production of

Table 3. pH and water holding capacity (WHC) of pork emulsion formulated with different forms of dietary fiber and ISP

\begin{tabular}{lccccc}
\hline \multirow{2}{*}{ Traits } & \multicolumn{4}{c}{ Types of binding agent } \\
\cline { 3 - 6 } & & ISP (control) & Wheat & Oat & Bamboo shoot \\
\hline $\mathrm{pH}$ & Uncooked & $5.68 \pm 0.04$ & $5.65 \pm 0.01$ & $5.65 \pm 0.01$ & $5.65 \pm 0.01$ \\
& Cooked & $5.81 \pm 0.05$ & $5.81 \pm 0.03$ & $5.79 \pm 0.01$ & $5.80 \pm 0.02$ \\
\hline \multirow{2}{*}{ WHC (\%) } & Uncooked & $13.49 \pm 0.14^{\mathrm{b}}$ & $15.78 \pm 0.82^{\mathrm{a}}$ & $16.05 \pm 0.45^{\mathrm{a}}$ & $15.98 \pm 0.72^{\mathrm{a}}$ \\
& Cooked & $18.18 \pm 0.54^{\mathrm{b}}$ & $19.74 \pm 0.72^{\mathrm{a}}$ & $19.45 \pm 0.41^{\mathrm{a}}$ & $20.36 \pm 0.61^{\mathrm{a}}$ \\
\hline
\end{tabular}

All values are mean $\pm \mathrm{SD}$.

${ }^{a, b}$ Means in the same row with different letters are significantly different $(p<0.05)$.

ISP, isolated soy protein; WHC, water holding capacity. 
emulsified meat in the meat processing industry.

The WHC of the pork emulsion produced using different forms of dietary fiber and ISP is presented in Table 3. Raw and after cooking, the $\mathrm{WHC}$ of the dietary fiber-treated groups were significantly higher value than ISP-treated group $(p<0.05)$. In line with the results of this study, Talukder and Sharma [19] found that for ground meat products, the WHC increases with the addition of wheat bran and oat bran with a high content of dietary fiber, and Biswas et al. [2] reported that the dietary fibers extracted from carrageenan, wood pulp, bamboo, and wheat can enhance the WHC of meat products.

\section{Emulsion stability and cooking loss}

The emulsion stability and cooking loss of the pork emulsions produced using different forms of dietary fiber and ISP are shown in Fig. 1. For emulsion stability, water loss and fat loss were $18.55 \%-23.09 \%$ and $2.13 \%-4.32 \%$, respectively, but no significant difference was observed among the various forms of dietary fiber and ISP. For cooking loss, the loss in the ISP-treated group was found to be significantly higher than those of the fiber-treated groups $(p<0.05)$. The group treated with oat fiber exhibited a significantly lower value than the ISP or wheat fiber groups $(p<0.05)$; the bamboo shoot fiber group did not differ significantly from the wheat or oat fiber groups. In line with the results of this study, the addition of dietary fiber as a binding agent in the production of emulsified or ground meat has been reported to enhance the emulsion stability and reduce cooking loss $[7,19]$. At the meat product, outstanding WHC was known as lead to decrease of cooking loss [20]. Thus, the addition of dietary fiber as an ISP replacement could reduce the loss in emulsified meat products, based on which an economic benefit is anticipated.

\section{Viscosity}

The viscosity of the pork emulsions produced using different forms of dietary fiber and ISP is shown in Fig. 2. ISP increases the viscosity when added to food products between liquid and semi-solid states [13], and the addition of ISP is also known to increase the viscosity of emulsified meat [14]. The viscosity of the pork emulsion produced using various forms of dietary fiber and ISP did not show a significant difference among the dietary fiber-treated groups (108.18-113.16 Pa . s), whereas the ISP-treated group showed a lower value of viscosity $(89.42 \mathrm{~Pa} \cdot \mathrm{s})$ than the dietary fiber-treated groups. Choi et al. [7] reported that the separate addition of ISP and wheat during

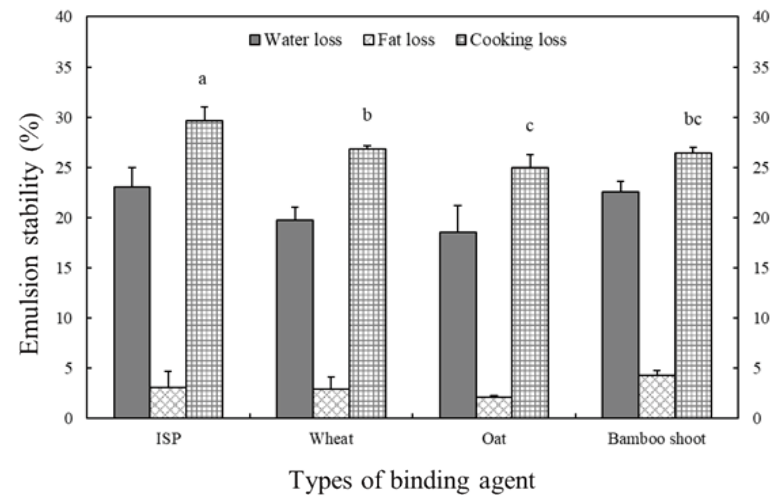

Fig. 1. Emulsion stability and cooking loss of pork emulsion formulated with different forms of dietary fiber and ISP. ${ }^{a-c}$ Means in the same bar with different letters are significantly different $(p<0.05)$. ISP, isolated soy protein.

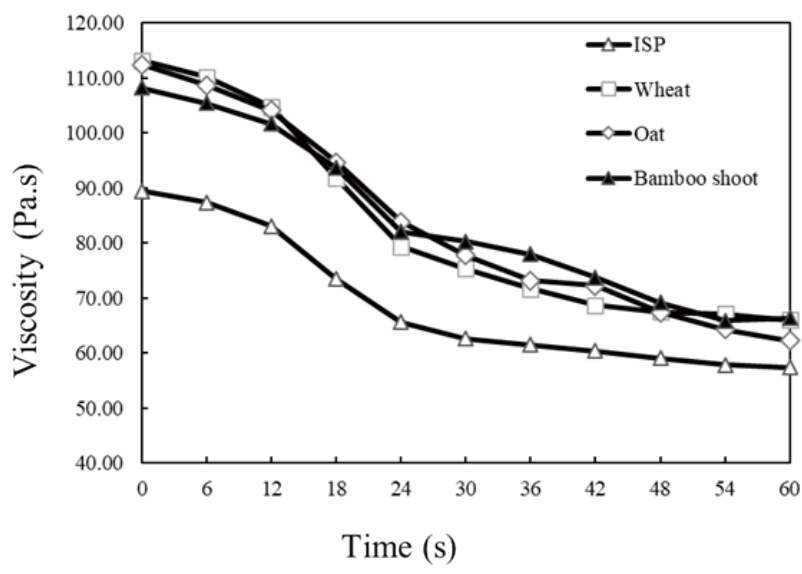

Fig. 2. Viscosity of pork emulsion formulated with different forms of dietary fiber and ISP. ISP, isolated soy protein. 
the production of sausage emulsion resulted in a similar increase in viscosity, which was in line with reports where the addition of dietary fiber to low-fat emulsified meat products led to an increase in viscosity [21,22]. The processed meat products can maintain a stable state during the emulsion process as a reticular structure is organized among water, protein, and fat [23]. This leads to a degree of viscosity, which is used as the main indicator of the emulsion level and stability for emulsified meat products [24]. Thus, present results showed indicated dietary fiber has led to excellent stability of emulsifier as a binding agent.

TPA

The texture profile analysis (TPA) of the pork emulsions produced using different forms of dietary fiber and ISP is presented in Table 4. Soy protein is a textured soy protein (TSP) that has been used in the food industry to enhance food texture $[13,14]$. Dietary fibers can also enhance the texture, which has made them suitable for use as a fat replacement [2,16]. The TPA results showed that springiness, gumminess, and chewiness did not exhibit significant intergroup differences, whereas hardness displayed a significantly lower value in the ISP-treated group than in the dietary fiber-treated groups $(p<0.05)$. No significant difference was found across the different fiber-treated groups. On the contrary, cohesiveness showed a significantly higher value in the ISP-treated group compared with those in the dietary fiber-treated groups $(p<0.05)$, with the different fiber-treated groups showing no significant intergroup difference. Eim et al. [17] reported that upon the addition of carrot fiber to ground meat products, hardness increases with the increasing amount of added dietary fiber. Fernandez-gines et al. [18] reported that when the amount of citrus fiber exceeds a certain level during the production of bologna sausage, hardness increases and cohesiveness decreases, as was the case in this study. Thus, considering the physicochemical properties, the addition of dietary fiber as an ISP replacement is anticipated to enable the production of emulsified meat products with a firm texture.

\section{CONCLUSION}

The present study analyzed the quality properties of pork emulsion manufactured replacing the ISP as a binding agent for different forms (wheat, oat, and bamboo shoot) of dietary fibers. Important factors as a binding agent, WHC and cooking loss of dietary fiber-treated groups were excellent more than ISP-treated group. In case of viscosity, dietary fiber-treated groups were higher than ISP-treated group. Therefore, dietary fibers can replace ISP as a binding agent for pork emulsion.

Table 4. Texture profile analysis of pork emulsion formulated with different forms of dietary fiber and ISP

\begin{tabular}{lcccc}
\hline \multirow{2}{*}{ Traits } & \multicolumn{4}{c}{ Types of binding agent } \\
\cline { 2 - 5 } & ISP (control) & Wheat & Oat & Bamboo shoot \\
\hline Hardness $(\mathrm{N})$ & $18.61 \pm 1.03^{\mathrm{b}}$ & $23.60 \pm 2.35^{\mathrm{a}}$ & $23.48 \pm 1.50^{\mathrm{a}}$ & $23.63 \pm 0.94^{\mathrm{a}}$ \\
Springness & $0.92 \pm 0.02$ & $0.92 \pm 0.02$ & $0.90 \pm 0.03$ & $0.92 \pm 0.01$ \\
Cohesiveness & $0.42 \pm 0.04^{\mathrm{a}}$ & $0.34 \pm 0.05^{\mathrm{b}}$ & $0.33 \pm 0.01^{\mathrm{b}}$ & $0.32 \pm 0.07^{\mathrm{b}}$ \\
Gumminess $(\mathrm{N})$ & $7.88 \pm 0.40$ & $7.88 \pm 0.51$ & $7.74 \pm 0.56$ & $7.50 \pm 1.80$ \\
Chewiness $(\mathrm{N})$ & $7.21 \pm 0.44$ & $7.24 \pm 0.47$ & $6.93 \pm 0.53$ & $6.90 \pm 1.71$ \\
\hline
\end{tabular}

All values are mean $\pm \mathrm{SD}$.

a,b Means in the same row with different letters are significantly different $(p<0.05)$

ISP, isolated soy protein. 


\section{REFERENCES}

1. Fernandez-Gines JM, Fernendez-Lopez J, Sayas-Barbera E, Perez-Alvarez JA. Meat products as functional foods: a review. J Food Sci. 2005;70:R37-43.

2. Biswas AK, Kumar V, Bhosle S, Sahoo J, Chatli MK. Dietary fibers as functional ingredients in meat products and their role in human health. Int J Livest Prod. 2011;2:45-54.

3. Talukder S. Effect of dietary fiber on properties and acceptance of meat products: a review. Crit Rev Food Sci Nutr. 2015;55:1005-11.

4. Roberfroid M. Dietary fiber, inulin, and oligofructose: a review comparing their physiological effects. Crit Rev Food Sci Nutr. 1993;33:103-48.

5. Brown L, Rosner B, Willett WW, Sacks FM. Cholesterol-lowering effects of dietary fiber: a meta-analysis. Am J Clin Nutr. 1999;69:30-42.

6. Steenblock RL, Sebranek JG, Olson DG, Love JA. The effects of oat fiber on the properties of light bologna and fat-free frankfurters. J Food Sci. 2001;66:1409-15.

7. Choi YS, Lee MA, Jeong JY, Choi JH, Han DJ, Kim HY, et al. Effects of wheat fiber on the quality of meat batter. Korean J Food Sci Anim Resour. 2007;27:22-8.

8. Huang SC, Tsai YF, Chen CM. Effects of wheat fiber, oat fiber, and inulin on sensory and physico-chemical properties of chinese-style sausages. Asian-Australas J Anim Sci. 2011;24:875-80.

9. AOAC [Association of Official Analytical Chemists] International. Official methods of analysis of AOAC International. 15th ed. Washington, DC: AOAC International; 1990.

10. Cabling MM, Kang HS, Lopez BM, Jang M, Kim HS, Nam KC, et al. Estimation of genetic associations between production and meat quality traits in duroc pigs. Asian-Australas J Anim Sci. 2015;28:1061-5.

11. Ensor SA, Mandigo RW, Calkins CR, Quint LN. Comparative evaluation of whey protein concentrate, soy protein isolate and calcium-reduced nonfat dry milk as binders in an emulsion-type sausage. J Food Sci. 1987;52:1155-8.

12. Choi YS, Choi JH, Han DJ, Kim HY, Lee MA, Kim HW, et al. Characteristics of low-fat meat emulsion systems with pork fat replaced by vegetable oils and rice bran fiber. Meat Sci. 2009;82:266-71.

13. Rakosky J. Soy products for the meat industry. J Agric Food Chem. 1970;18:1005-9.

14. Singh P, Kumar R, Sabapathy SN, Bawa AS. Functional and edible uses of soy protein products. Compr Rev Food Sci Food Saf. 2008;7:14-28.

15. Fernandez-Gines JM, Fernandez-Lopez J, Sayas-Barbera E, Sendra E, Perez-Alvarez JA. Lemon albedo as a new source of dietary fiber: application to bologna sausages. Meat Sci. 2004;67:7-13.

16. Choe JH, Kim HY, Lee JM, Kim YJ, Kim CJ. Quality of frankfurter-type sausages with added pig skin and wheat fiber mixture as fat replacers. Meat Sci. 2013;93:849-54.

17. Eim VS, Simal S, Rossello C, Femenia A. Effects of addition of carrot dietary fibre on the ripening process of a dry fermented sausage (sobrassada). Meat Sci. 2008;80:173-82.

18. Fernandez-Gines JM, Fernandez-Lopez J, Sayas-Barbera E, Sendra E, Perez-Alvarez JA. Effect of storage conditions on quality characteristics of bologna sausages made with citrus fiber.J Food Sci. 2003;68:710-4.

19. Talukder S, Sharma DP. Development of dietary fiber rich chicken meat patties using wheat and oat bran.J Food Sci Technol. 2010;47:224-9.

20. Park SY, Kim HY, Choe J. Application of an electric field refrigeration system on pork loin during dry aging. Food Sci Anim Resour. 2019;39:668-76. 
21. Choi YS, Choi JH, Han DJ, Kim HY, Lee MA, Kim HW, et al. Characteristics of low-fat meat emulsion systems with pork fat replaced by vegetable oils and rice bran fiber. Meat Sci. 2009;82:266-71.

22. Grigelmo-Miguel N, Abadias-Seros MI, Martin-Belloso O. Characterisation of low-fat high-dietary fibre frankfurters. Meat Sci. 1999;52:247-56.

23. Acton JC, Ziegler GR, Burge DL, Froning GW. Functionality of muscle constituents in the processing of comminuted meat products. Crit Rev Food Sci Nutr. 1983;18:99-121.

24. Yapar A, Atay S, Kayacier A, Yetim H. Effects of different levels of salt and phosphate on some emulsion attributes of the common carp (Cyprinus carpio L., 1758). Food Hydrocoll. 2006;20:825-30. 